\title{
Role of transcription factor FOXA1 in non-small cell lung cancer
}

\author{
JIA LI $^{1}$, SHIRONG ZHANG ${ }^{2}$, LUCHENG ZHU $^{1}$ and SHENGLIN MA ${ }^{1}$ \\ ${ }^{1}$ Department of Oncology; ${ }^{2}$ Center for Translational Medicine, Hangzhou First People's Hospital, \\ Nanjing Medical University, Hangzhou, Zhejiang 310006, P.R. China
}

Received January 31, 2017; Accepted August 31, 2017

DOI: $10.3892 / \mathrm{mmr} .2017 .7885$

\begin{abstract}
In our previous study, stable subpopulations of the A549 lung cancer cell line with high/low invasive potential (H/L-INV) were obtained. In the present study, microarray analysis of the H/L-INV A549 subpopulations was performed to evaluate genes associated with high invasiveness. Forkhead box protein A1 (FOXA1) was selected for further investigation. The expression levels of FOXA1 in the primary lesion and metastatic lymph nodes were assessed using reverse transcription-quantitative polymerase chain reaction (RT-qPCR) analysis. In addition, the mRNA and protein expression levels of FOXA1 were examined in H-INV A549 cells transfected with a specific FOXA1 small interfering RNA (siRNA), and the role of FOXA1 in the proliferation, invasion and metastasis of non-small cell lung cancer (NSCLC) cells was evaluated. FOXA1 was overexpressed in metastatic lymph nodes, compared with its expression in NSCLC primary tumours. The results of western blot and RT-qPCR analyses confirmed that FOXA1 siRNA transfection led to a decrease in the expression of FOXA1 in H-INV A549 cells. FOXA1 siRNA transfection caused G0/G1 phase cell cycle arrest, and also reduced the invasion, migration and proliferation abilities of the H-INV A549 cells. In conclusion, the results of the present study suggested that FOXA1 is a potential oncogene in NSCLC; therefore, specific interference of the expression of FOXA1 may represent a novel approach for the treatment of NSCLC.
\end{abstract}

\section{Introduction}

Among malignant tumours, lung cancer poses the greatest threat to human health, and non-small cell lung cancer (NSCLC) accounts for $85-90 \%$ of all lung cancer cases. Metastasis is present in the majority of patients with NSCLC

Correspondence to: Professor Shenglin Ma, Department of Oncology, Hangzhou First People's Hospital, Nanjing Medical University, 6 Xiaonv Road, Shangcheng, Hangzhou, Zhejiang 310006, P.R. China

E-mail: mashenglin@medmail.com.cn

Key words: forkhead box protein A1, non-small cell lung cancer, gene microarray, RNA interference, molecular targeted therapy upon diagnosis, and surgery is an option in only $20 \%$ of cases. Local and distal NSCLC metastases are the major causes of treatment failure (1). There is currently no effective prophylactic treatment against NSCLC metastasis available. Therefore, it is important to investigate the mechanisms underlying the invasion and metastasis of NSCLC.

In our previous study, the invasive/metastatic potential of NSCLC cells were analysed using an in vitro tumour cell invasion assay (2). Transwell inserts were used, and a Transwell membrane with an appropriate pore size was coated with basement membrane extract (BME). Those cells with a high invasive/metastatic potential migrated to the lower surface of the membrane or to the lower chamber. By repeated screening, stable subpopulations of high/low invasive potential (H/L-INV) were obtained from the A549 lung cancer cell line, and from prostate, breast and colon cancer cell lines (Fig. 1A). Analysis of the H/L-INV A549 cells revealed that the H-INV subpopulation exhibited the typical cancer stem cell phenotype (CD24 ${ }^{\text {low }} / \mathrm{CD} 44^{+}$and CD133), but the L-INV subpopulation did not (Fig. 1B).

In the present study, microarray analysis of the H/L-INV A549 subpopulations was performed to evaluate genes associated with high invasiveness, and Forkhead box protein A1 (FOXA1) was selected for further investigation. The expression levels of FOXA1 in primary lesions and metastatic lymph nodes were assessed via reverse transcription-quantitative polymerase chain reaction (RT-qPCR) analysis. In addition, the mRNA and protein expression levels of FOXA1 were examined in H-INV A549 cells transfected with a specific FOXA1 small interfering RNA (siRNA), and the role of FOXA1 in proliferation, invasion and metastasis in the NSCLC cells was evaluated.

\section{Materials and methods}

Cell culture. The human A549 lung cancer cell line was obtained from the American Type Culture Collection (Manassas, VA, USA). The H/L-INV A549 cells were obtained by repeated Transwell screening and routinely cultured in RPMI-1640 medium supplemented with $10 \%$ foetal bovine serum (FBS) and penicillin/streptomycin (all from Sigma-Aldrich; Merck Millipore, Darmstadt, Germany). The cells were incubated at $37^{\circ} \mathrm{C}$ in $5 \% \mathrm{CO}_{2}$.

Gene microarray. Total RNA was extracted from the H/L-INV A549 cells with TRIzol reagent (Invitrogen; Thermo Fisher 
Scientific, Inc., Waltham, MA, USA). The mRNA was purified using the RNeasy Mini kit (Qiagen, Inc., Valencia, CA, USA) and reverse transcribed into cDNA, which was transcribed to biotin-labelled cRNA using T7 DNA polymerase (Invitrogen; Thermo Fisher Scientific, Inc.). The cRNA samples were fragmented into fragments of between 50 and $100 \mathrm{nt}$ in fragmentation buffer (Invitrogen; Thermo Fisher Scientific, Inc.). The fragmented cRNA was dissolved in hybridization buffer (Invitrogen; Thermo Fisher Scientific, Inc.) and hybridised with the GeneChip (Illumina, Inc., San Diego, CA, USA) at $45^{\circ} \mathrm{C}$ for $16 \mathrm{~h}$. The chip was then washed and stained according to the manufacturer's protocol and scanned using an Illumina BeadArray reader. Microarray Suite 5.0 (Affymetrix, Inc., Santa Clara, CA, USA) was used to comprehensively analyse and compare the microarray data.

To identify the genes with high invasive/metastatic potential, genes with significantly different expression levels between H-INV A549 and L-INV A549 were examined. The gene sets with $\geq 2$-fold differences in mRNA levels are shown in Tables I and II.

NSCLC specimen collection. A total of 40 pairs of primary tumour tissues and corresponding metastatic lymph nodes were collected from patients who underwent tumour resection at Hangzhou Hospital Affiliated to Nanjing Medical University (Hangzhou, China) between 2014 and 2015. The tissues were confirmed to be NSCLC by post-operative pathological evaluation. The fresh specimens were frozen in liquid nitrogen and stored at $-80^{\circ} \mathrm{C}$. The present study was approved by the ethics committee of Nanjing Medical University and was performed with the provision of written informed consent from patients.

RT-qPCR analysis. Total RNA was extracted from the tissues and cells using TRIzol reagent (Invitrogen; Thermo Fisher Scientific, Inc.). cDNA was synthesised from $1 \mu \mathrm{g}$ of total RNA and used as a template in a 50- $\mu 1$ reaction using TaqMan RT reagents according to the manufacturer's protocol (Applied Biosystems; Thermo Fisher Scientific, Inc.). The RT-qPCR was performed to amplify genes from the cDNA template with gene-specific primer sets. The following PCR primers were used: FOXA1, forward 5'-TAATCATTGCCATCGTGT GCTT-3' and reverse 5'-ATAATGAAACCCGTCTGGCTA-3'; GAPDH, forward 5'-ATCCCATCACCATCTTCCAGGAGC G-3' and reverse 5'-AAATGAGCCCCAGCCTTCTCCATG-3'. To avoid amplifying genomic DNA, gene primers were selected from different exons. The reaction was performed in a total reaction volume of $50 \mu \mathrm{l}$, which contained $2 \mu \mathrm{l}$ of cDNA solution, $0.2 \mu \mathrm{M}$ sense and antisense primers, $25 \mu \mathrm{l}$ GoTaq qPCR Master mix (Promega Corporation, Madison, WI, USA) and DEPC-treated water. The amplification conditions were as follows: Pre-denaturation at $95^{\circ} \mathrm{C}$ for $10 \mathrm{~min}$, followed by $35-40$ cycles of denaturation at $95^{\circ} \mathrm{C}$ for $15 \mathrm{sec}$, and annealing and extension at $60^{\circ} \mathrm{C}$ for $1 \mathrm{~min}$. The relative expression level of FOXA1 was calculated using the comparative $\mathrm{Cq}(\Delta \Delta \mathrm{Cq})$ method (expression fold value $=2^{-\Delta \Delta \mathrm{Cq}}$ ) (3), using GAPDH as the internal reference. Each sample was measured in triplicate.

$H-I N V$ A549 transfection with siRNA. FOXA1 siRNA and the negative control siRNA were purchased from Biotend (Shanghai, China). The siRNA sequences were as follows:
FOXA1 siRNA-1: 5'-GUACUACCA AGGUGUGUAUdT dT-3'; FOXA1 siRNA-2: 5'-CUGUCCUUCAAUGACUGC UdTdT-3'; FOXA1 siRNA-3: 5'-CGUCCUUCAACAUGU CCUAdTdT-3'. The cells were divided into three groups: Non-transfected, Ctrl-siRNA and FOXA1-siRNA. In vitro transfections were performed using Lipofectamine 2000 (Invitrogen; Thermo Fisher Scientific, Inc.). The cells were seeded in 6-well plates in 1,500 $\mu 1$ of RPMI-O-MEM without antibiotics or FBS $\left(1.5 \times 10^{6}\right.$ cells/well). Upon reaching $30-50 \%$ confluence, the cells were transfected with $500 \mu \mathrm{l}$ of transfection mixture containing 20,30 or $50 \mathrm{nM}$ siRNA. The cells were washed $6 \mathrm{~h}$ following transfection and harvested at 24 or $48 \mathrm{~h}$ post-transfection for subsequent experiments.

Western blot analysis. Total proteins were extracted from the cells of the three groups described above $48 \mathrm{~h}$ following transfection. The cell lysates were centrifuged at $16,000 \mathrm{x} \mathrm{g}$ for $10 \mathrm{~min}$ at $4^{\circ} \mathrm{C}$, and the supernatant was collected and stored at $-20^{\circ} \mathrm{C}$. The protein concentration was determined using a BCA assay kit (Pierce; Thermo Fisher Scientific, Inc.), and $50 \mu \mathrm{g}$ of protein was loaded into each well and subjected to sodium dodecyl sulfate-polyacrylamide gel electrophoresis. The proteins were then transferred onto a nitrocellulose membrane (Immobilon-P; EMD Millipore, Bedford, MA, USA) in an ice bath at $80 \mathrm{~V}$. Subsequently, the membrane was blocked using 5\% skim milk (Bio-Rad Laboratories, Inc., Hercules, CA, USA) and incubated with 1:1,000 dilutions of either rabbit FOXA1 antibody (cat no. 58613; Cell Signaling Technology, Inc., Danvers, MA, USA) or rabbit $\beta$-actin antibody (cat no. 4970; Cell Signaling Technology, Inc.) as the primary antibody overnight at $4^{\circ} \mathrm{C}$. Following washing with Tris-buffered saline solution containing 1\% Tween-20 the membrane was incubated with horseradish peroxidase-conjugated goat anti-rabbit IgG secondary antibody (cat no. 4412; dilution 1:5,000; Cell Signalling Technology, Inc.) at room temperature for $1 \mathrm{~h}$. Finally, the proteins were detected using enhanced chemiluminescence (GE Healthcare Life Sciences, Upsulla, Sweden). The molecular mass (kDa) of the proteins was determined using the prestained protein marker (Bio-Rad Laboratories, Inc., Hercules, California, USA). The blot image was analysed using Image-Pro Plus software version 6.0 (Media Cybernetics, Inc., Rockville, MD, USA). FOXA1 and $\beta$-actin IOD values were obtained, and the relative value of the target protein was indicated by the IOD ratio of the target protein to $\beta$-actin in the same sample. This experiment was repeated three times.

In vitro Transwell invasion and migration assays. Each 8- $\mu \mathrm{m}$ insert membrane (Falcon; BD Biosciences, Franklin Lakes, NJ, USA) was coated with $50 \mu \mathrm{l}$ of BME gel (Tervigen, Gaithersburg, MD, USA) and incubated overnight at $37^{\circ} \mathrm{C}$. The non-transfected, FOXA1-siRNA (24 h post-transfection) and Ctrl-siRNA cells were subjected to the assay in triplicate. The cell suspension was adjusted to $2 \times 10^{5}$ cells $/ \mathrm{ml}$ in RPMI-1640 with $0.1 \%$ FBS, and $200 \mu 1$ of cell suspension was added to each Transwell. The lower compartment contained $600 \mu 1$ of RPMI-1640 with $10 \%$ FBS. After $48 \mathrm{~h}$, the cells on the upper surface of the membrane were wiped off, and the membrane was fixed in methanol for $15 \mathrm{~min}$, followed by staining with 
Table I. Total 153 genes with >2-fold upregulation in H-INV cells vs. L-INV cells.

\begin{tabular}{|c|c|c|c|c|c|}
\hline \multirow{2}{*}{ Gene } & \multirow{2}{*}{ P-value (H vs. L) } & \multirow{2}{*}{ Fold-change (H vs. L) } & & P-value (H vs. L) & Fo \\
\hline & & & NINJ1 & $2 \mathrm{E}-07$ & 2.3 \\
\hline PI3 & $1 \mathrm{E}-12$ & 29.7 & AMOT & $6 \mathrm{E}-07$ & 2.3 \\
\hline IL13RA2 & $2 \mathrm{E}-11$ & 25.4 & E2F2 & 3E-09 & 2.3 \\
\hline SOST & $2 \mathrm{E}-12$ & 13.8 & CXORF57 & $4 \mathrm{E}-07$ & 2.3 \\
\hline PRND & $2 \mathrm{E}-12$ & 12.4 & DMKN & 3E-09 & 2.2 \\
\hline LOC653879 & $3 \mathrm{E}-13$ & 11.4 & IRX3 & 4E-09 & 2.2 \\
\hline CES1 & $3 \mathrm{E}-13$ & 11.3 & MMP7 & $3 \mathrm{E}-08$ & 2.2 \\
\hline LCP1 & $2 \mathrm{E}-13$ & 10.7 & TMSB15A & $1 \mathrm{E}-08$ & 2.2 \\
\hline KRT81 & $4 \mathrm{E}-13$ & 10.4 & TMEM47 & $3 \mathrm{E}-08$ & 2.2 \\
\hline THBS1 & $1 \mathrm{E}-10$ & 10.1 & NFKBIA & $6 \mathrm{E}-08$ & 2.2 \\
\hline NNMT & $6 \mathrm{E}-11$ & 9.3 & HS.373429 & $9 \mathrm{E}-10$ & 2.2 \\
\hline COL9A2 & $5 \mathrm{E}-11$ & 8.8 & NXT2 & $2 \mathrm{E}-07$ & 2.2 \\
\hline CLIC3 & $5 \mathrm{E}-12$ & 8.4 & GINS2 & $1 \mathrm{E}-07$ & 2.2 \\
\hline OLFML3 & $1 \mathrm{E}-11$ & 8.3 & SPOCK1 & 2E-07 & 2.2 \\
\hline LOC 100133511 & 2E-09 & 7.0 & IGFBP6 & $3 \mathrm{E}-08$ & 2.2 \\
\hline TGFA & $2 \mathrm{E}-11$ & 6.3 & GPC4 & $2 \mathrm{E}-08$ & 2.1 \\
\hline EVI1 & 9E-11 & 6.1 & FBN2 & 7E-08 & 2.1 \\
\hline FLJ35767 & 4E-10 & $\begin{array}{l}5.8 \\
5.2\end{array}$ & TGM2 & 5E-09 & 2.1 \\
\hline C3 & $1 \mathrm{E}-11$ & $\begin{array}{l}5.3 \\
5.2\end{array}$ & SCARNA9 & $2 \mathrm{E}-05$ & 2.1 \\
\hline TNIP1 & 2E-10 & $\begin{array}{l}5.2 \\
5.1\end{array}$ & TUBB2B & $5 \mathrm{E}-09$ & 2.0 \\
\hline TNIP3 & $1 \mathrm{E}-10$ & $\begin{array}{l}5.1 \\
5.1\end{array}$ & SMAD6 & $5 \mathrm{E}-08$ & 2.0 \\
\hline $\begin{array}{l}\text { FZD4 } \\
\text { SI } 1243\end{array}$ & $\begin{array}{l}3 \mathrm{E}-09 \\
1 \mathrm{~F}_{-} 09\end{array}$ & $\begin{array}{l}5.1 \\
50\end{array}$ & AKR1B15 & 4E-06 & 2.0 \\
\hline $\begin{array}{l}\text { SLC12A3 } \\
\text { BST2 }\end{array}$ & $\begin{array}{l}1 \mathrm{E}-09 \\
6 \mathrm{E}_{-}-11\end{array}$ & $\begin{array}{l}5.0 \\
48\end{array}$ & FAM111A & $6 \mathrm{E}-09$ & 2.0 \\
\hline $\begin{array}{l}\mathrm{BST} 2 \\
\mathrm{COBL} 1\end{array}$ & $\begin{array}{l}6 \mathrm{E}-11 \\
9 \mathrm{E}-11\end{array}$ & $\begin{array}{l}4.8 \\
3.3\end{array}$ & IFIH1 & $3 \mathrm{E}-07$ & 2.0 \\
\hline $\begin{array}{l}\text { NOBLL1 } \\
\text { NDN }\end{array}$ & $\begin{array}{l}\text { YE-11 } \\
5 \mathrm{E}-08\end{array}$ & $\begin{array}{l}5.3 \\
3.3\end{array}$ & NES & $1 \mathrm{E}-06$ & 2.0 \\
\hline $\begin{array}{l}\text { NDN } \\
\text { HS.568928 }\end{array}$ & $\begin{array}{l}5 \mathrm{E}-08 \\
2 \mathrm{E}-09\end{array}$ & $\begin{array}{l}3.5 \\
3.3\end{array}$ & DLG4 & $1 \mathrm{E}-08$ & 2.0 \\
\hline ZC3H12A & $6 \mathrm{E}-10$ & 3.3 & IL1A & $8 \mathrm{E}-10$ & 4.7 \\
\hline LOC 100134370 & $6 \mathrm{E}-08$ & 3.2 & LOC100134134 & $2 \mathrm{E}-11$ & 4.6 \\
\hline F2RL2 & $4 \mathrm{E}-10$ & 3.2 & ARHGAP4 & $2 \mathrm{E}-10$ & 4.3 \\
\hline LOC 100132240 & 3E-09 & 3.2 & CLDN11 & $5 \mathrm{E}-10$ & 4.2 \\
\hline SULT1A2 & $2 \mathrm{E}-11$ & 3.2 & LOC100129681 & $2 \mathrm{E}-10$ & 4.1 \\
\hline HKDC1 & 1E-09 & 3.1 & CES4 & $2 \mathrm{E}-11$ & 4.0 \\
\hline PLTP & $4 \mathrm{E}-13$ & 3.1 & SULT1A4 & $3 \mathrm{E}-11$ & 4.0 \\
\hline KCTD14 & $1 \mathrm{E}-08$ & 3.0 & ARHGEF5L & $5 \mathrm{E}-12$ & 3.9 \\
\hline GSTM1 & $2 \mathrm{E}-10$ & 3.0 & ARAP3 & $2 \mathrm{E}-10$ & 3.9 \\
\hline SULT1A1 & $2 \mathrm{E}-10$ & 3.0 & $\mathrm{DIO} 2$ & $3 \mathrm{E}-10$ & 3.9 \\
\hline FOXA1 & $5 \mathrm{E}-10$ & 3.0 & SNAI2 & $1 \mathrm{E}-12$ & 3.8 \\
\hline LYPD6 & $4 \mathrm{E}-08$ & 3.0 & LOC648815 & $7 \mathrm{E}-11$ & 3.8 \\
\hline WWC1 & 4E-08 & 2.9 & PLAC8 & 3E-09 & 3.7 \\
\hline ARHGEF5 & $7 \mathrm{E}-10$ & 2.9 & CCND3 & $6 \mathrm{E}-09$ & 3.6 \\
\hline SLFN11 & 9E-09 & 2.8 & PTGDS & 7E-09 & 3.6 \\
\hline ID1 & 7E-09 & 2.8 & OLFM1 & $9 \mathrm{E}-10$ & 3.5 \\
\hline SLPI & $2 \mathrm{E}-08$ & 2.7 & GBP1 & 3E-09 & 3.5 \\
\hline TBC1D9 & $6 \mathrm{E}-09$ & 2.7 & EFNB2 & $3 E-11$ & 3.5 \\
\hline PVRL3 & $1 \mathrm{E}-08$ & 2.7 & CTDSPL & $1 \mathrm{E}-10$ & 3.5 \\
\hline GSTM3 & $1 \mathrm{E}-07$ & 2.7 & GAS1 & $2 \mathrm{E}-09$ & 3.5 \\
\hline ZDHHC23 & $1 \mathrm{E}-09$ & 2.3 & GCA & 4E-09 & 3.4 \\
\hline SLIT2 & 2E-09 & 2.3 & SERPINA3 & $5 \mathrm{E}-07$ & 3.4 \\
\hline C14ORF132 & 2E-09 & 2.3 & SPINK5L3 & $3 \mathrm{E}-08$ & 3.4 \\
\hline MAP1A & $3 \mathrm{E}-09$ & 2.3 & $\mathrm{CP}$ & $6 \mathrm{E}-09$ & 2.7 \\
\hline DBNDD2 & $8 \mathrm{E}-08$ & 2.3 & MAOA & $1 \mathrm{E}-07$ & 2.6 \\
\hline EMP1 & $1 \mathrm{E}-08$ & 2.3 & ID3 & $1 \mathrm{E}-08$ & 2.6 \\
\hline
\end{tabular}

Table I. Continued.

\section{(a)}


Table I. Continued.

\begin{tabular}{|c|c|c|}
\hline Gene & P-value (H vs. L) & Fold-change (H vs. L) \\
\hline SPARC & $5 \mathrm{E}-07$ & 2.6 \\
\hline CCDC74B & $3 \mathrm{E}-08$ & 2.6 \\
\hline WDR69 & 1E-09 & 2.6 \\
\hline KLHDC8B & $1 \mathrm{E}-09$ & 2.6 \\
\hline IL7R & $3 \mathrm{E}-10$ & 2.5 \\
\hline GSTM2 & $1 \mathrm{E}-07$ & 2.5 \\
\hline BMP7 & $6 \mathrm{E}-09$ & 2.5 \\
\hline CASP1 & $6 \mathrm{E}-10$ & 2.5 \\
\hline C6ORF150 & 3E-09 & 2.5 \\
\hline CAMK2N1 & $9 \mathrm{E}-10$ & 2.5 \\
\hline SALL2 & $2 \mathrm{E}-07$ & 2.5 \\
\hline NUP210 & 5E-09 & 2.5 \\
\hline AXL & 7E-08 & 2.5 \\
\hline CEBPD & $3 \mathrm{E}-08$ & 2.4 \\
\hline CCR1 & 4E-08 & 2.4 \\
\hline ANKRD41 & $5 \mathrm{E}-10$ & 2.4 \\
\hline ZNF467 & $2 \mathrm{E}-10$ & 2.4 \\
\hline STRA6 & $2 \mathrm{E}-07$ & 2.4 \\
\hline NFKBIZ & 3E-09 & 2.4 \\
\hline PDLIM3 & $1 \mathrm{E}-11$ & 2.4 \\
\hline CCDC74A & $5 \mathrm{E}-07$ & 2.1 \\
\hline DUSP2 & $1 \mathrm{E}-06$ & 2.1 \\
\hline TGFBR3 & $4 \mathrm{E}-08$ & 2.1 \\
\hline GPX3 & $1 \mathrm{E}-06$ & 2.1 \\
\hline FLYWCH2 & 3E-09 & 2.1 \\
\hline FAT1 & $3 \mathrm{E}-08$ & 2.1 \\
\hline DBC1 & $1 \mathrm{E}-08$ & 2.1 \\
\hline HEBP1 & $2 \mathrm{E}-08$ & 2.1 \\
\hline PRPS2 & 4E-09 & 2.1 \\
\hline RPS23 & $2 \mathrm{E}-08$ & 2.1 \\
\hline SOX2 & $2 \mathrm{E}-08$ & 2.1 \\
\hline EGFLAM & $2 \mathrm{E}-10$ & 2.1 \\
\hline MAMLD1 & $1 \mathrm{E}-07$ & 2.1 \\
\hline CLDN23 & $3 \mathrm{E}-08$ & 2.1 \\
\hline KCNK1 & $2 \mathrm{E}-08$ & 2.1 \\
\hline EPM2AIP1 & $1 \mathrm{E}-07$ & 2.1 \\
\hline LITAF & $6 \mathrm{E}-08$ & 2.1 \\
\hline LMTK3 & 9E-07 & 2.1 \\
\hline C8ORF4 & $3 \mathrm{E}-07$ & 2.1 \\
\hline NEFL & $7 \mathrm{E}-07$ & 2.1 \\
\hline LOC 158376 & $5 \mathrm{E}-09$ & 2.1 \\
\hline KIF15 & $3 \mathrm{E}-06$ & 2.0 \\
\hline ACSL4 & $2 \mathrm{E}-07$ & 2.0 \\
\hline CDCP1 & $2 \mathrm{E}-06$ & 2.0 \\
\hline SH3GL3 & $1 \mathrm{E}-07$ & 2.0 \\
\hline UNC13C & $5 \mathrm{E}-10$ & 2.0 \\
\hline PPEF1 & 2E-09 & 2.0 \\
\hline SULT1A3 & 8E-09 & 2.0 \\
\hline EPSTI1 & $3 \mathrm{E}-07$ & 2.0 \\
\hline PNMA2 & $5 \mathrm{E}-07$ & 2.0 \\
\hline COL3A1 & $2 \mathrm{E}-06$ & 2.0 \\
\hline
\end{tabular}

H, A549/H-INV; L, A549/L-INV.
Table II. Total 297 genes with >2 fold-change downregulation in H-INV cells vs. L-INV cells.

\begin{tabular}{|c|c|c|}
\hline Gene & P-value (H vs. L) & Fold-change (H vs. L) \\
\hline TBC1D19 & 4E-07 & -2.0 \\
\hline ZNF277 & 2E-06 & -2.0 \\
\hline MIF4GD & 4E-07 & -2.0 \\
\hline SH3BGRL3 & $6 \mathrm{E}-07$ & -2.0 \\
\hline MACROD1 & $8 \mathrm{E}-07$ & -2.0 \\
\hline FAM46A & 3E-09 & -2.0 \\
\hline PTGER4 & $8 \mathrm{E}-08$ & -2.0 \\
\hline PLAUR & $5 \mathrm{E}-11$ & -2.0 \\
\hline TBX2 & $1 \mathrm{E}-08$ & -2.0 \\
\hline HIST3H2A & $3 \mathrm{E}-06$ & -2.0 \\
\hline ZNF365 & $7 \mathrm{E}-10$ & -2.0 \\
\hline PLCB1 & 7E-07 & -2.0 \\
\hline $\mathrm{COCH}$ & $6 \mathrm{E}-08$ & -2.0 \\
\hline $\mathrm{CFH}$ & $6 \mathrm{E}-09$ & -2.0 \\
\hline PLOD3 & 4E-08 & -2.1 \\
\hline EPGN & 4E-07 & -2.1 \\
\hline PTPRM & $3 \mathrm{E}-08$ & -2.1 \\
\hline CCDC68 & 2E-09 & -2.1 \\
\hline GLCE & 4E-07 & -2.1 \\
\hline CD226 & 4E-09 & -2.1 \\
\hline SYT1 & 3E-09 & -2.1 \\
\hline CALU & $1 \mathrm{E}-07$ & -2.1 \\
\hline BST2 & $6 \mathrm{E}-11$ & 4.8 \\
\hline PDE7B & $1 \mathrm{E}-08$ & -2.2 \\
\hline C7ORF68 & 2E-07 & -2.2 \\
\hline CA2 & 2E-08 & -2.2 \\
\hline AHNAK2 & $6 \mathrm{E}-06$ & -2.2 \\
\hline HS.4892 & $3 \mathrm{E}-08$ & -2.2 \\
\hline HBQ1 & $1 \mathrm{E}-08$ & -2.2 \\
\hline CRIM1 & $8 \mathrm{E}-08$ & -2.2 \\
\hline AADAC & $8 \mathrm{E}-08$ & -2.2 \\
\hline PMEPA1 & 2E-08 & -2.2 \\
\hline PDE1A & $1 \mathrm{E}-10$ & -2.2 \\
\hline GMDS & 2E-07 & -2.2 \\
\hline TSPAN7 & $1 \mathrm{E}-08$ & -2.2 \\
\hline VEGFC & $6 \mathrm{E}-07$ & -2.2 \\
\hline GDPD5 & $1 \mathrm{E}-07$ & -2.2 \\
\hline MYPN & 4E-09 & -2.2 \\
\hline SERPINB1 & 2E-07 & -2.2 \\
\hline HEBP2 & $8 \mathrm{E}-07$ & -2.2 \\
\hline CYFIP2 & $7 \mathrm{E}-10$ & -2.2 \\
\hline PPAPDC1B & 3E-09 & -2.2 \\
\hline FHL1 & 2E-09 & -2.2 \\
\hline ITFG1 & 4E-08 & -2.2 \\
\hline EPB41L3 & $4 \mathrm{E}-08$ & -2.2 \\
\hline NR4A2 & $3 \mathrm{E}-07$ & -2.2 \\
\hline SH3RF1 & $1 \mathrm{E}-08$ & -2.2 \\
\hline AHCYL2 & $1 \mathrm{E}-06$ & -2.2 \\
\hline NFIA & $1 \mathrm{E}-07$ & -2.2 \\
\hline ADM2 & 4E-08 & -2.2 \\
\hline MTHFD2L & 5E-09 & -2.2 \\
\hline
\end{tabular}


Table II. Continued.

\begin{tabular}{|c|c|c|c|c|c|}
\hline Gene & P-value (H vs. L) & Fold-change (H vs. L) & Gene & P-value (H vs. L) & Fold-change (H vs. L) \\
\hline MN1 & $1 \mathrm{E}-10$ & -2.2 & ISG20 & 2E-09 & -3.5 \\
\hline EGR1 & 2E-06 & -2.2 & VGF & 2E-09 & -3.5 \\
\hline XYLT1 & $2 \mathrm{E}-10$ & -2.2 & GJA1 & $1 \mathrm{E}-08$ & -3.5 \\
\hline TFB1M & 3E-08 & -2.2 & C9ORF167 & $3 \mathrm{E}-08$ & -3.5 \\
\hline TMEM106B & 4E-07 & -2.2 & KLF2 & $2 \mathrm{E}-10$ & -3.6 \\
\hline NCOA7 & 7E-06 & -2.2 & SCARA5 & $1 \mathrm{E}-10$ & -3.6 \\
\hline ACAT2 & 3E-09 & -2.2 & LGR4 & $8 \mathrm{E}-10$ & -3.6 \\
\hline EFNA1 & 4E-07 & -2.2 & NRIP1 & $2 \mathrm{E}-10$ & -3.6 \\
\hline QPCT & 2E-09 & -2.3 & SLC16A14 & $1 \mathrm{E}-10$ & -3.6 \\
\hline PKIA & 2E-09 & -2.3 & GPR65 & $1 \mathrm{E}-10$ & -3.6 \\
\hline LOC645993 & $1 \mathrm{E}-06$ & -2.3 & CLDN1 & $3 \mathrm{E}-08$ & -3.6 \\
\hline BMPER & 2E-08 & -2.3 & FLJ14213 & $1 \mathrm{E}-09$ & -3.7 \\
\hline MFGE8 & $5 \mathrm{E}-08$ & -2.3 & DOCK11 & $2 \mathrm{E}-11$ & -3.7 \\
\hline ELL2 & $5 \mathrm{E}-09$ & -2.3 & BMP6 & 3E-09 & -3.7 \\
\hline HS.444329 & 2E-07 & -2.3 & HS.133181 & 2E-09 & -3.8 \\
\hline LEPREL2 & $4 \mathrm{E}-12$ & -2.3 & PYGB & $2 \mathrm{E}-08$ & -3.9 \\
\hline LYPD1 & $2 \mathrm{E}-11$ & -2.3 & DUSP1 & $2 \mathrm{E}-08$ & -3.9 \\
\hline TXNIP & $6 \mathrm{E}-06$ & -2.3 & FLRT2 & $6 \mathrm{E}-09$ & -3.9 \\
\hline VAV3 & $6 \mathrm{E}-10$ & -2.5 & PRICKLE1 & 1E-09 & -3.9 \\
\hline HS.193557 & $2 \mathrm{E}-07$ & -2.5 & SRPX & $2 \mathrm{E}-10$ & -3.9 \\
\hline INSL4 & 4E-08 & -2.6 & PION & $2 \mathrm{E}-08$ & -4.0 \\
\hline KCNMB4 & 8E-09 & -2.6 & ESM1 & $8 \mathrm{E}-10$ & -4.0 \\
\hline LOC 100130506 & $1 \mathrm{E}-07$ & -2.6 & HCLS1 & $8 \mathrm{E}-11$ & -4.1 \\
\hline HS.551128 & $2 \mathrm{E}-10$ & -2.6 & TSPAN13 & $2 \mathrm{E}-10$ & -4.9 \\
\hline PLA2G4A & $5 \mathrm{E}-08$ & -2.6 & GPR37 & 3E-09 & -4.9 \\
\hline PDLIM5 & $3 \mathrm{E}-10$ & -2.6 & TSC22D1 & $4 \mathrm{E}-10$ & -4.9 \\
\hline PDE4D & $3 \mathrm{E}-07$ & -2.6 & SPATA7 & $4 \mathrm{E}-10$ & -4.9 \\
\hline LOC644070 & $6 \mathrm{E}-10$ & -2.6 & GDF15 & $3 \mathrm{E}-10$ & -5.0 \\
\hline CNN3 & $3 \mathrm{E}-07$ & -2.7 & SERPINB11 & $2 \mathrm{E}-11$ & -5.1 \\
\hline DPYD & 4E-09 & -2.7 & MALL & $2 \mathrm{E}-12$ & -5.1 \\
\hline PNMA1 & $1 \mathrm{E}-10$ & -2.7 & LAMB1 & $6 \mathrm{E}-11$ & -5.2 \\
\hline SOX4 & $5 \mathrm{E}-08$ & -2.7 & CDH10 & 4E-09 & -5.3 \\
\hline AGPAT9 & 9E-07 & -2.7 & CITED2 & $9 \mathrm{E}-11$ & -5.3 \\
\hline IRS2 & $5 \mathrm{E}-08$ & -2.7 & KIAA1199 & 1E-09 & -5.3 \\
\hline LOC 100134073 & $1 \mathrm{E}-08$ & -2.7 & SERPINE2 & $1 \mathrm{E}-10$ & -5.4 \\
\hline IL8 & 1E-09 & -2.7 & DKK1 & $2 \mathrm{E}-10$ & -5.4 \\
\hline BMP5 & $1 \mathrm{E}-08$ & -2.7 & FOXC1 & $1 \mathrm{E}-08$ & -5.6 \\
\hline SLC2A1 & 4E-09 & -2.7 & ALDH3A1 & 1E-09 & -5.6 \\
\hline CXCL5 & 8E-09 & -2.7 & EPHA4 & $5 \mathrm{E}-11$ & -5.8 \\
\hline LXN & $8 \mathrm{E}-11$ & -2.8 & TMX4 & $2 \mathrm{E}-12$ & -5.8 \\
\hline LOC 124220 & 7E-09 & -2.8 & LGALS3 & 8E-09 & -6.2 \\
\hline C13ORF15 & 2E-09 & -3.0 & SLC7A2 & $1 \mathrm{E}-12$ & -6.2 \\
\hline C14ORF72 & $4 \mathrm{E}-07$ & -3.0 & SERPIND1 & $6 \mathrm{E}-10$ & -6.2 \\
\hline IRS1 & $4 \mathrm{E}-10$ & -3.0 & JUP & $2 \mathrm{E}-10$ & -6.8 \\
\hline PERP & $8 \mathrm{E}-08$ & -3.0 & PITPNC1 & $5 \mathrm{E}-11$ & -6.8 \\
\hline SLC16A6 & $5 \mathrm{E}-10$ & -3.1 & PRDM8 & $9 \mathrm{E}-11$ & -7.1 \\
\hline TUBB3 & 1E-09 & -3.1 & CYR61 & $5 \mathrm{E}-07$ & -2.1 \\
\hline CD55 & 9E-07 & -3.1 & LOC388755 & $7 \mathrm{E}-12$ & -2.1 \\
\hline CKB & 7E-09 & -3.1 & TSC22D3 & $8 \mathrm{E}-10$ & -2.1 \\
\hline MOCOS & $6 \mathrm{E}-10$ & -3.1 & HS.25318 & $2 \mathrm{E}-07$ & -2.1 \\
\hline DCBLD2 & $1 \mathrm{E}-08$ & -3.1 & GLRX & $6 \mathrm{E}-08$ & -2.1 \\
\hline ALDOC & $6 \mathrm{E}-09$ & -3.1 & GPT2 & $3 \mathrm{E}-08$ & -2.1 \\
\hline
\end{tabular}

Table II. Continued. 
Table II. Continued.

\begin{tabular}{|c|c|c|c|c|c|}
\hline Gene & P-value (H vs. L) & Fold-change (H vs. L) & Gene & P-value (H vs. L) & Fold-change (H vs. L) \\
\hline PHF10 & $1 \mathrm{E}-06$ & -2.1 & HNMT & $3 \mathrm{E}-10$ & -2.4 \\
\hline C9ORF5 & $2 \mathrm{E}-07$ & -2.1 & EZR & $4 \mathrm{E}-08$ & -2.4 \\
\hline MEF2C & 4E-07 & -2.1 & ANKRD32 & $1 \mathrm{E}-07$ & -2.4 \\
\hline HS.552826 & 7E-06 & -2.1 & HS.492187 & 4E-08 & -2.4 \\
\hline TMEM84 & $2 \mathrm{E}-08$ & -2.1 & ARID5B & $1 \mathrm{E}-09$ & -2.4 \\
\hline CTSL1 & $1 \mathrm{E}-08$ & -2.1 & ANXA10 & 2E-09 & -2.4 \\
\hline ULK1 & $1 \mathrm{E}-08$ & -2.1 & GALIG & 8E-09 & -2.4 \\
\hline MT2A & $1 \mathrm{E}-06$ & -2.1 & RPH3AL & 7E-09 & -2.4 \\
\hline C6ORF48 & $2 \mathrm{E}-08$ & -2.1 & PRKAR1A & 7E-09 & -2.4 \\
\hline MIR302C & 2E-09 & -2.1 & FAM129A & 7E-07 & -2.4 \\
\hline SMOC1 & $1 \mathrm{E}-08$ & -2.1 & TMEM100 & $3 \mathrm{E}-08$ & -2.4 \\
\hline LOC730074 & $5 \mathrm{E}-07$ & -2.1 & SYTL2 & $3 \mathrm{E}-12$ & -2.8 \\
\hline PDGFRL & $6 \mathrm{E}-11$ & -2.1 & CTGF & $6 \mathrm{E}-09$ & -2.8 \\
\hline TMEM2 & 7E-09 & -2.1 & VIL2 & 3E-09 & -2.8 \\
\hline RAB38 & 4E-09 & -2.2 & VASN & $8 \mathrm{E}-08$ & -2.8 \\
\hline PTPN12 & $6 \mathrm{E}-07$ & -2.2 & LAMC1 & $2 \mathrm{E}-08$ & -2.8 \\
\hline C10ORF140 & $4 \mathrm{E}-11$ & -2.2 & ABCA8 & $2 \mathrm{E}-11$ & -2.8 \\
\hline CDKN1A & $1 \mathrm{E}-07$ & -2.4 & MTHFD1L & $2 \mathrm{E}-08$ & -2.8 \\
\hline SERPINB5 & $4 \mathrm{E}-11$ & -2.4 & MARCKS & $4 \mathrm{E}-10$ & -2.8 \\
\hline OAS1 & $3 \mathrm{E}-10$ & -2.4 & MBP & $8 \mathrm{E}-08$ & -2.8 \\
\hline SOCS3 & 5E-09 & -2.4 & WDFY2 & 4E-11 & -2.9 \\
\hline BTG1 & 7E-07 & -2.4 & CD163L1 & $3 \mathrm{E}-08$ & -2.9 \\
\hline GOLSYN & $1 \mathrm{E}-08$ & -2.4 & GLDC & $2 \mathrm{E}-07$ & -2.9 \\
\hline TGFBR2 & $1 \mathrm{E}-09$ & -2.4 & SPRY2 & $6 \mathrm{E}-08$ & -2.9 \\
\hline TNFAIP3 & $2 \mathrm{E}-08$ & -2.4 & CSRP1 & $9 \mathrm{E}-10$ & -2.9 \\
\hline C1ORF24 & $5 \mathrm{E}-06$ & -2.4 & CADPS2 & 1E-09 & -2.9 \\
\hline CENPV & 9E-08 & -2.4 & TNFRSF21 & $3 \mathrm{E}-08$ & -3.0 \\
\hline HBA2 & $2 \mathrm{E}-08$ & -2.4 & TGFB2 & 2E-09 & -3.0 \\
\hline NCKAP5 & $5 \mathrm{E}-10$ & -2.4 & SEMA3A & $5 \mathrm{E}-07$ & -3.0 \\
\hline TMEM154 & 2E-08 & -2.5 & SEPP1 & 3E-09 & -3.0 \\
\hline RGS2 & $3 \mathrm{E}-06$ & -2.5 & ASNS & 2E-09 & -3.0 \\
\hline SHC4 & 7E-09 & -2.5 & HS.24119 & 2E-09 & -3.0 \\
\hline STX1A & $5 \mathrm{E}-07$ & -2.5 & DDIT3 & $8 \mathrm{E}-08$ & -3.0 \\
\hline CSGALNACT1 & 4E-09 & -2.5 & TTC32 & 3E-09 & -3.0 \\
\hline PCSK1 & 3E-09 & -2.5 & KLF4 & $3 \mathrm{E}-11$ & -3.2 \\
\hline PDE1C & 2E-09 & -2.5 & ZFP36 & 9E-09 & -3.2 \\
\hline CNTNAP1 & $5 \mathrm{E}-08$ & -2.5 & MYO5C & 3E-09 & -3.2 \\
\hline CTNNAL1 & 2E-09 & -2.5 & CDH1 & $4 \mathrm{E}-10$ & -3.2 \\
\hline SAT1 & 1E-09 & -2.5 & WDR72 & 9E-08 & -3.2 \\
\hline CA12 & 8E-09 & -2.5 & FJX1 & $7 \mathrm{E}-11$ & -3.3 \\
\hline HOPX & 9E-08 & -2.3 & UBE2L6 & $3 \mathrm{E}-11$ & -3.3 \\
\hline LRP11 & $3 \mathrm{E}-08$ & -2.3 & RAB31 & 1E-09 & -3.3 \\
\hline HBE1 & $3 \mathrm{E}-08$ & -2.3 & C20ORF108 & 1E-09 & -3.3 \\
\hline MAP7 & $1 \mathrm{E}-10$ & -2.3 & KRT80 & 4E-09 & -3.3 \\
\hline HERPUD1 & $7 \mathrm{E}-10$ & -2.3 & DEFB1 & $1 \mathrm{E}-10$ & -3.4 \\
\hline HS.579530 & $2 \mathrm{E}-07$ & -2.3 & ERRFI1 & $2 \mathrm{E}-08$ & -4.1 \\
\hline MET & $5 \mathrm{E}-08$ & -2.3 & FAM107B & 7E-09 & -4.1 \\
\hline PDLIM1 & $1 \mathrm{E}-10$ & -2.3 & EDN1 & $8 \mathrm{E}-12$ & -4.1 \\
\hline SNCA & 1E-09 & -2.3 & SUCNR1 & 9E-09 & -4.1 \\
\hline GKN1 & $3 \mathrm{E}-07$ & -2.3 & ADAM19 & $3 \mathrm{E}-13$ & -4.1 \\
\hline DDAH1 & $1 \mathrm{E}-06$ & -2.4 & C5ORF46 & $3 \mathrm{E}-10$ & -4.3 \\
\hline TIMP1 & $9 \mathrm{E}-10$ & -2.4 & FAM113B & 1E-09 & -4.4 \\
\hline
\end{tabular}

Table II. Continued. 
Table II. Continued.

\begin{tabular}{|c|c|c|}
\hline Gene & P-value (H vs. L) & Fold-change (H vs. L) \\
\hline GREM2 & $3 \mathrm{E}-10$ & -4.4 \\
\hline CYP24A1 & 1E-09 & -4.5 \\
\hline CAV1 & $2 \mathrm{E}-10$ & -4.5 \\
\hline M160 & 3E-09 & -4.5 \\
\hline C13ORF30 & $3 \mathrm{E}-10$ & -4.6 \\
\hline FST & $7 \mathrm{E}-11$ & -4.6 \\
\hline STS-1 & $1 \mathrm{E}-10$ & -4.7 \\
\hline ITGA2 & $3 \mathrm{E}-12$ & -4.7 \\
\hline TNFRSF11B & $2 \mathrm{E}-11$ & -4.7 \\
\hline PDK4 & $2 \mathrm{E}-11$ & -4.8 \\
\hline C12ORF39 & 5E-09 & -4.8 \\
\hline ITPRIP & $1 \mathrm{E}-10$ & -4.8 \\
\hline NRCAM & $5 \mathrm{E}-10$ & -4.8 \\
\hline OLFML2A & $2 \mathrm{E}-11$ & -4.8 \\
\hline DDX10 & $7 \mathrm{E}-10$ & -4.8 \\
\hline LEPREL1 & $2 \mathrm{E}-10$ & -4.8 \\
\hline C1ORF85 & $3 \mathrm{E}-12$ & -7.1 \\
\hline RAB3C & $1 \mathrm{E}-10$ & -7.9 \\
\hline GSTO2 & $5 \mathrm{E}-12$ & -8.0 \\
\hline PAPPA & $6 \mathrm{E}-11$ & -8.0 \\
\hline LAMA1 & $3 \mathrm{E}-13$ & -8.1 \\
\hline GPR64 & $2 \mathrm{E}-12$ & -8.5 \\
\hline DLG2 & $6 \mathrm{E}-12$ & -9.2 \\
\hline TFPI & $2 \mathrm{E}-10$ & -9.2 \\
\hline ANTXR2 & $8 \mathrm{E}-13$ & -9.3 \\
\hline RSPO3 & 9E-11 & -10.2 \\
\hline $\mathrm{CD} 24$ & $8 \mathrm{E}-13$ & -10.3 \\
\hline FLJ21986 & $9 \mathrm{E}-14$ & -10.7 \\
\hline KRT19 & $4 \mathrm{E}-12$ & -13.2 \\
\hline IGFBP4 & $4 \mathrm{E}-12$ & -14.0 \\
\hline MLPH & $1 \mathrm{E}-12$ & -14.0 \\
\hline SERPINB2 & $2 \mathrm{E}-13$ & -16.9 \\
\hline TSPAN8 & $3 \mathrm{E}-10$ & -20.0 \\
\hline COL8A1 & $2 \mathrm{E}-13$ & -20.9 \\
\hline GALC & $3 \mathrm{E}-12$ & -29.5 \\
\hline AGR2 & $3 \mathrm{E}-16$ & -45.9 \\
\hline CDH11 & $1 \mathrm{E}-13$ & -49.4 \\
\hline PTGS2 & 6E-09 & -3.5 \\
\hline
\end{tabular}

H, A549/H-INV; L, A549/L-INV.

$1 \%$ rystal violet for $15 \mathrm{~min}$. Using a CX31 microscope (Olympus Corporation, Tokyo, Japan), five fields were randomly selected (magnification, x100) on each membrane and the number of the cells which had crossed the membrane were counted, with the average being calculated. The invasive potential of the tumour cells was measured using the relative invasion index (\%), which was calculated as follows: Relative invasion index $(\%)=$ (invading cell count of transfected cells/invading cell count of non-transfected cells) x100\%. To compare the migration ability of the three groups of cells, the experiment was performed in the same manner with the same method for counting following incubation for $24 \mathrm{~h}$, but without the BME gel coating on the Transwell membrane.

Scratch wound assay. The non-transfected, FOXA1-siRNA and Ctrl-siRNA cells were seeded in 6-well plates ( $3 \times 10^{6}$ cells/well). At $24 \mathrm{~h}$ post-transfection, a scratch was created across the bottom surface of each well with a sterile $200-\mu 1$ pipette tip. The detached cells were gently washed off with PBS, and the remaining cells were cultured with serum-free RPMI-1640. The cells along the scratch edges were observed under a CX31 microscope (Olympus Corporation) at 0,24 and $48 \mathrm{~h}$ post-scratch. The width of the scratch was measured at these time points, and the average scratch healing rate was calculated. The scratch healing rate was calculated as follows: Scratch healing rate $(\%)=($ scratch width at $0 \mathrm{~h}$-scratch width at $48 \mathrm{~h}$ )/scratch width at $0 \mathrm{~h} \times 100 \%$. This experiment was repeated three times.

MTS colorimetric assay. The non-transfected, FOXA1-siRNA ( $24 \mathrm{~h}$ post-transfection) and Ctrl-siRNA cells were seeded in 96-well plates at a density of 8,000 cells/100 $\mu \mathrm{l} /$ well. At 24, 48, 72 and $96 \mathrm{~h}$ post-seeding, $20 \mu \mathrm{l}$ of MTS (Promega Corporation, Madison, WI, USA) solution was added to each well and incubated for $1 \mathrm{~h}$. The absorbance at $490 \mathrm{~nm}$ was measured on a plate reader. The growth inhibition rate was calculated as follows: Growth inhibition rate $=$ (control group absorption-experiment group absorption)/control group absorption. This experiment was repeated three times.

Cell cycle analysis using flow cytometry. The non-transfected, FOXA1-siRNA (24 h post-transfection) and Ctrl-siRNA cells (1x10 ${ }^{6}$ each) were collected and washed in PBS. The cells were fixed and stained using a cell cycle staining kit (Multisciences Biotech Co., Ltd., Shanghai, China) according to the manufacturer's protocol. Flow cytometric analysis was performed using a BD FACSCalibur flow cytometer (BD Biosciences) equipped with a 488-nm argon-ion laser. This experiment was repeated three times.

Statistical analysis. Data were analysed using SPSS 16.0 (SPSS, Inc., Chicago, IL, USA) and expressed as the mean \pm standard deviation. Significant differences among multiple groups were analysed using one-way analysis of variance and the significance of pair-wise differences was analysed by Student's t-test. $\mathrm{P}<0.05$ was considered to indicate a statistically significant difference.

\section{Results}

Expression of FOXA1 is high in the H-INV A549 subpopulation. The microarray analysis revealed 450 differentially expressed genes with $\geq 2$-fold changes between the H-INV and the L-INV subpopulations. Among these genes, 297 and 153 genes were expressed at low and high levels, respectively, in the H-INV subpopulation. The results of the preliminary microarray data analysis are shown in Fig. 2 and Tables I and II. FOXA1 was expressed at a high level in the H-INV subpopulation of A549 cells, and the level of expression was 3 -fold higher, compared with that in the L-INV cells ( $\mathrm{P}=5 \mathrm{E}-10)$. 
A A549 cell invasion

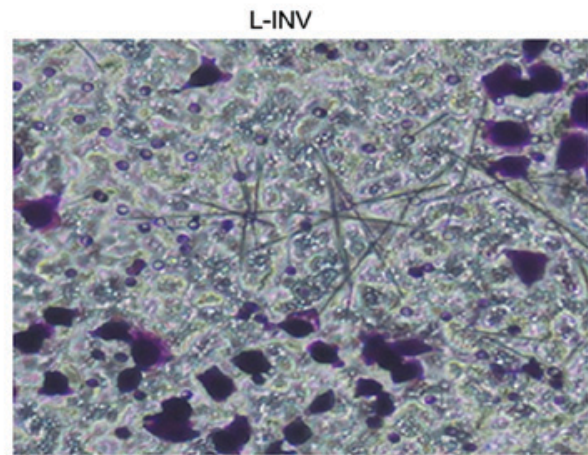

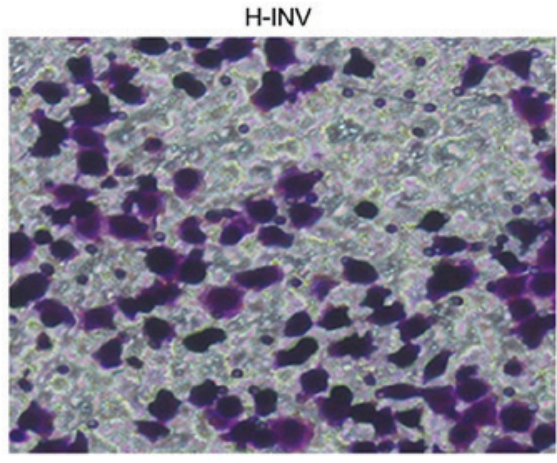

B Stem-cell surface markers
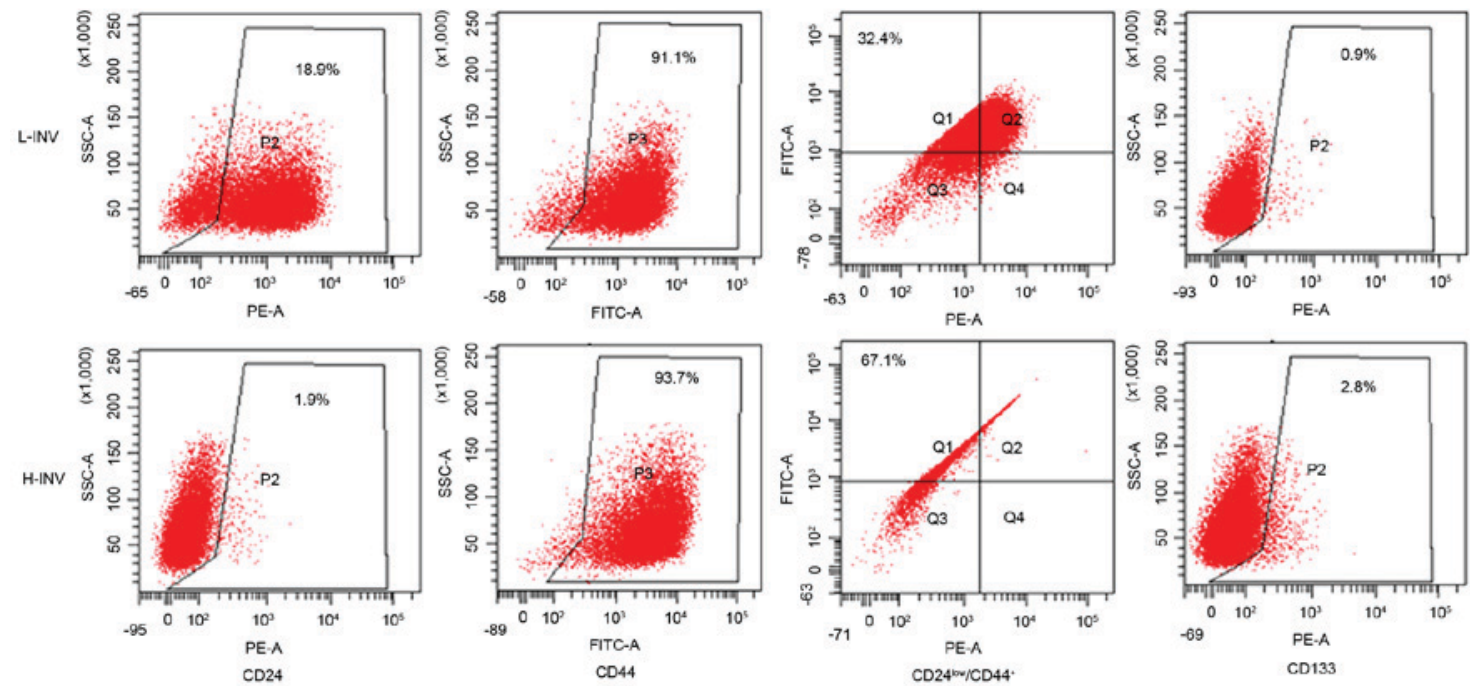

Figure 1. A549 cell invasion and stem cell surface markers in isolated cell populations. (A) H/L-INV A549 cells under a microscope (magnifications, x400). (B) Flow cytometry analysis for stem-cell surface markers in H/L-INV A549 cells. L-INV, low invasive potential; H-INV, high invasive potential.
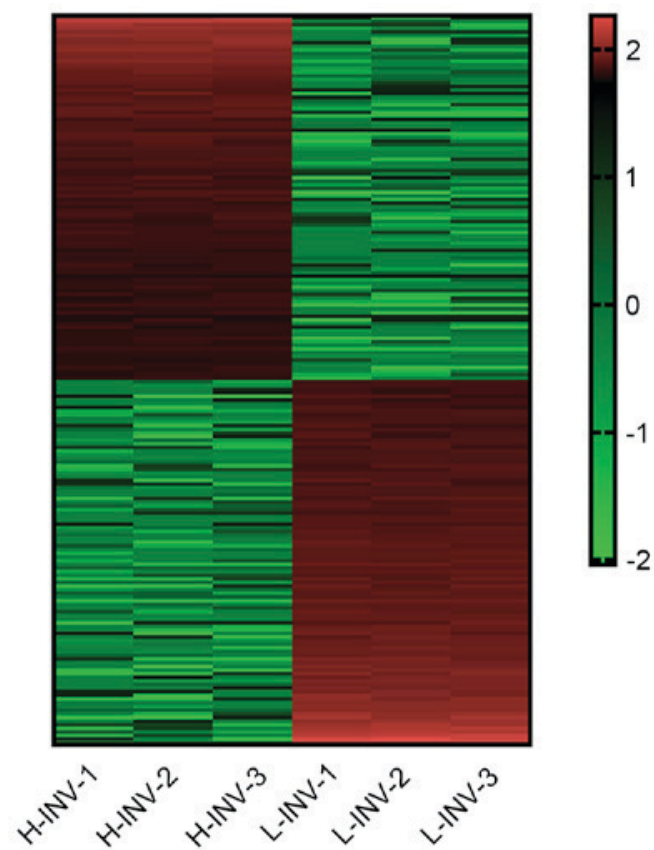

Figure 2. Functional clustering of genes associated with invasion in A549 H-INV vs. A549 L-INV cells. L-INV, low invasive potential; H-INV, high invasive potential. Red: A549/H-INV; Green: A549/L-INV.

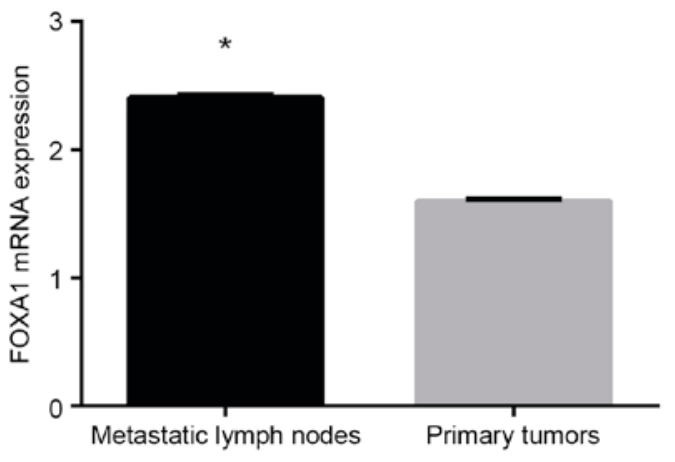

Figure 3. mRNA expression of FOXA1 in primary lesions and metastatic lymph nodes of non-small cell lung cancer ("P<0.05). FOXA1, forkhead box protein A1.

Expression of FOXAl is higher in metastatic lymph nodes, compared with NSCLC primary tumours. The mRNA expression of FOXA1 in 40 primary NSCLC tumours and 40 corresponding metastatic lymph nodes were examined using RT-qPCR analysis. FOXA1 mRNA was expressed in the primary NSCLC tumours and metastatic lymph nodes, and expression was higher in the metastatic lymph nodes, 
A

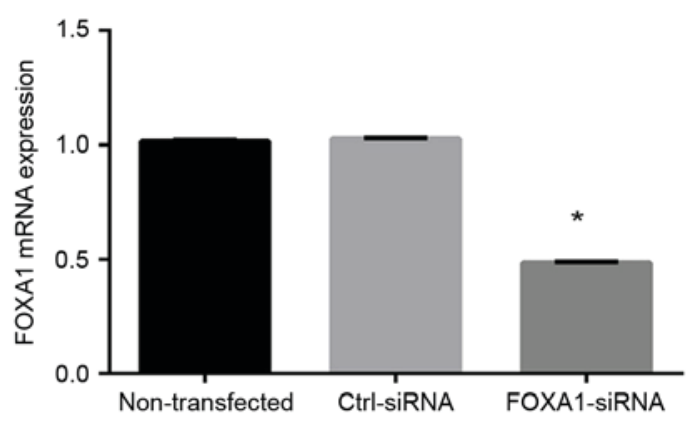

B
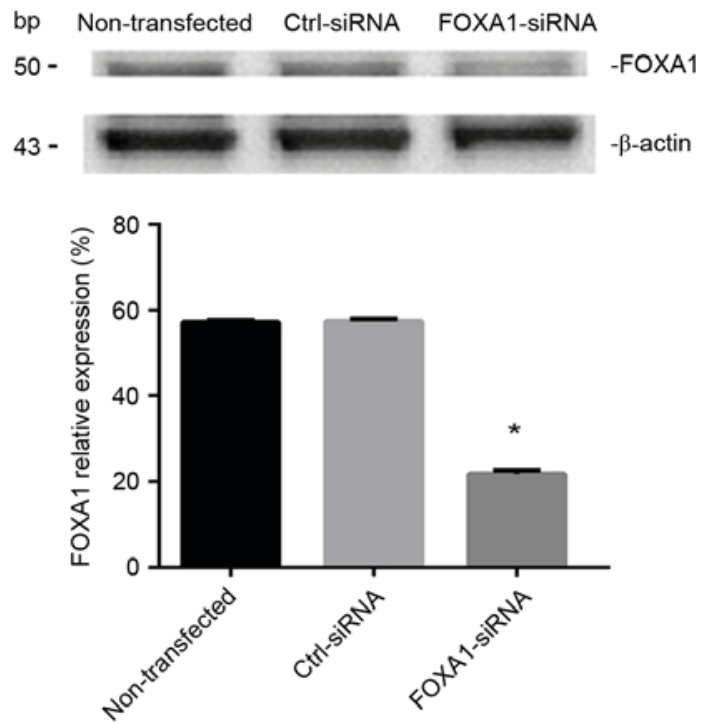

Figure 4. Expression of FOXA1 in A549 cells with high invasive potential following transfection. (A) Results of reverse transcription-quantitative polymerase chain reaction analysis $\left({ }^{*} \mathrm{P}<0.05\right.$ vs. other groups). (B) Results of western blot analysis ( $\mathrm{P}<0.05$ vs. other groups). FOXA1, forkhead box protein A1; Ctrl, control; siRNA, small interfering RNA.

compared with that in the corresponding primary tumour tissues $(\mathrm{P}<0.05$; Fig. 3).

mRNA expression of FOXA1 is reduced in FOXA1-siRNA transfected cells. The H-INV A549 cells were transfected with 20,30 or $50 \mathrm{nM}$ FOXA1 siRNA-1/2/3, and the mRNA expression of FOXA1 in each group was measured using RT-qPCR analysis 24 and $48 \mathrm{~h}$ following transfection. As shown in Fig. 4A, the mRNA expression level of FOXA1 was lowest in the cells transfected with FOXA1-siRNA-2 (30 nM; 24 h post-transfection; 0.485 \pm 0.007 ), which was significantly lower, compared with level in the non-transfected group $(1.015 \pm 0.062 ; \mathrm{P}<0.05)$ and the $\mathrm{Ctrl}$-siRNA group $(1.027 \pm 0.082 ; \mathrm{P}<0.05)$. There was no significant difference between the non-transfected and Ctrl-siRNA groups. On the basis of the above results, FOXA1-siRNA-2 was selected for use in subsequent experiments at the optimal transfection concentration of $30 \mathrm{nM}$ and examination duration of $24 \mathrm{~h}$ post-transfection.

Transfection with FOXA1-siRNA leads to a decrease in the protein expression of FOXA1. The results of the western
A
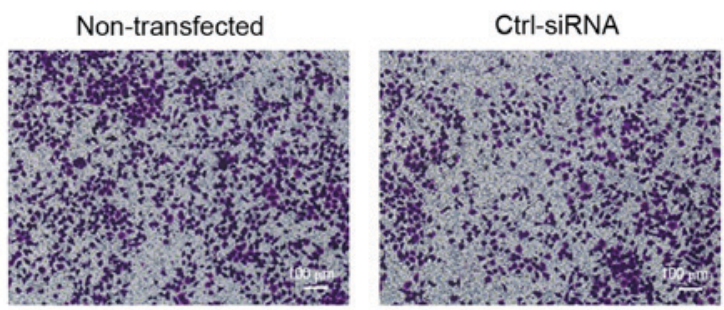

FOXA1-SiRNA
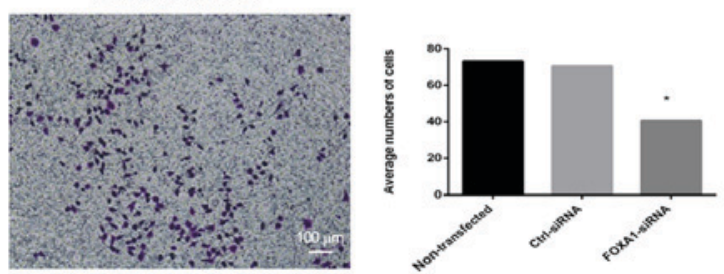

B
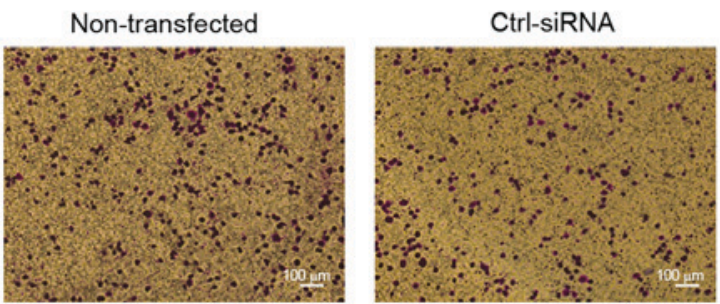

FOXA1-siRNA
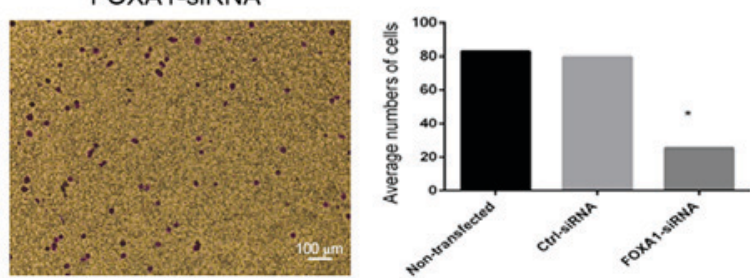

Figure 5. Cell invasion and migration of A549 cells with high invasive potential following transfection. (A) Results of the Transwell invasion assay (magnification, $\mathrm{x} 100$ ). The invasive ability of FOXA1- siRNA cells was significantly lower than that of the Ctrl-siRNA and non-transfected cells ( $\mathrm{P}<0.05$ ); (B) Results of the Transwell migration assay (magnification, $\mathrm{x} 100)$. The migratory ability of FOXA1-siRNA cells was significantly lower than that of the Ctrl-siRNA and non-transfected cells $\left({ }^{*} \mathrm{P}<0.05\right)$. FOXA1, forkhead box protein A1; Ctrl, control; siRNA, small interfering RNA.

blot analysis showed that the protein expression of FOXA1 was significantly reduced in the FOXA1-siRNA transfected H-INV A549 cells $48 \mathrm{~h}$ following transfection, compared with the expression levels in the non-transfected and Ctrl-siRNA-transfected cells $(\mathrm{P}<0.05$; Fig. 4B). There was no significant difference between the non-transfected and Ctrl-siRNA groups. This result confirmed that FOXA1-siRNA reduced the protein expression of FOXA1 in the H-INV A549 cells.

Transfection with FOXA1-siRNA reduces the invasion and migration abilities of $H-I N V$ A549 cells. The results of the Transwell invasion assay showed that the number of invading cells in the FOXA1-siRNA group was 40.60 \pm 0.89 , with an invasion index of $59 \pm 0.37 \%$, whereas the number of invading cells in the Ctrl-siRNA group was $70.40 \pm 1.22$, with an invasion index of $96 \pm 0.46 \%$. The invasive potentials of the FOXA1-siRNA and Ctrl-siRNA-transfected cells were 
Table III. Effect of FOXA1-siRNA on growth of high invasive potential A549 cells.

Cell growth inhibition rate $(\%)$

\begin{tabular}{lcccc}
\cline { 2 - 5 } Group & $24 \mathrm{~h}$ & $48 \mathrm{~h}$ & $72 \mathrm{~h}$ & $96 \mathrm{~h}$ \\
\hline FOXA1-siRNA & $0.3573 \pm 0.055^{\mathrm{a}}$ & $0.5081 \pm 0.001^{\mathrm{a}}$ & $0.5439 \pm 0.013^{\mathrm{a}}$ & $0.2904 \pm 0.001$ \\
Ctrl-siRNA & $0.0646 \pm 0.029$ & $0.0506 \pm 0.018$ & $0.0456 \pm 0.070$ & $0.0374 \pm 0.700$ \\
\hline
\end{tabular}

Using non-transfected cells as a control, data are presented as the mean \pm standard deviation. ${ }^{\mathrm{a}} \mathrm{P}<0.05$ vs. Ctrl-siRNA at 24,48 and $72 \mathrm{~h}$. FOXA1, forkhead box protein A1; Ctrl, control; siRNA, small interfering RNA.

significantly different $(\mathrm{P}<0.05$; Fig. 5A). This result indicated that downregulation of the gene expression of FOXA1 reduced the invasiveness of the metastatic A549 cells.

The Transwell migration assay showed that the numbers of cells crossing the membrane were $25.20 \pm 0.35,82.77 \pm 0.56$ and $79.72 \pm 0.28$ in the FOXA1-siRNA, non-transfected and Ctrl-siRNA groups, respectively. The number of cells crossing the membrane was significantly lower in the FOXA1-siRNA group, compared with that in the Ctrl-siRNA and non-transfected groups $(\mathrm{P}<0.05$; Fig. 5B). This result demonstrated that FOXA1 siRNA effectively reduced the migration ability of the H-INV A549 cells in vitro.

In the scratch wound assay, no significant differences were found in the scratch healing rates within $48 \mathrm{~h}$ post-scratching between the non-transfected group and the Ctrl-siRNA group ( $35.34 \pm 6.68$ and $34.45 \pm 4.08 \%$, respectively). By contrast, the healing rate in the FOXA1-siRNA cells was $19.66 \pm 5.05 \%$, revealing significantly reduced migration ability (Fig. 6).

FOXA1-siRNA decreases H-INV A549 proliferation activity. The MTS assay showed that transfection with FOXA1-siRNA (24 h post-transfection) led to significant growth inhibition at 24, 48 and $72 \mathrm{~h}(\mathrm{P}<0.05$; Table III).

FOXA1-siRNA induces G0/G1 arrest in H-INV A549 cells. Cell cycle was assessed using flow cytometry $24 \mathrm{~h}$ following transfection. As shown in Table IV, $49.31 \pm 3.20 \%$ of the non-transfected cells and $49.69 \pm 3.51 \%$ of the Ctrl-siRNA transfected cells were in the G0/G1 phase, with no significant difference between these two groups. By contrast, the FOXA1-siRNA group exhibited a significantly higher percentage of cells in the $\mathrm{G} 0 / \mathrm{G} 1$ phase $(58.99 \pm 3.20 \%$; $\mathrm{P}<0.05)$, suggesting that FOXA1-silencing induced G0/G1 arrest in the H-INV A549 cells (Fig. 7).

\section{Discussion}

In terms of lung cancer-associated mortality, $\sim 90 \%$ of cases are due to tumour cell invasion and metastasis (3). Distal metastasis is already present in $\sim 40-50 \%$ of patients with lung cancer patients at the time of diagnosis and develops in the remaining $50-60 \%$ of patients during the course of treatment (4). Clinical data indicate that $\sim 30 \%$ of patients with late-stage NSCLC who receive the targeted drug epidermal growth factor receptor tyrosine kinase inhibitor develop

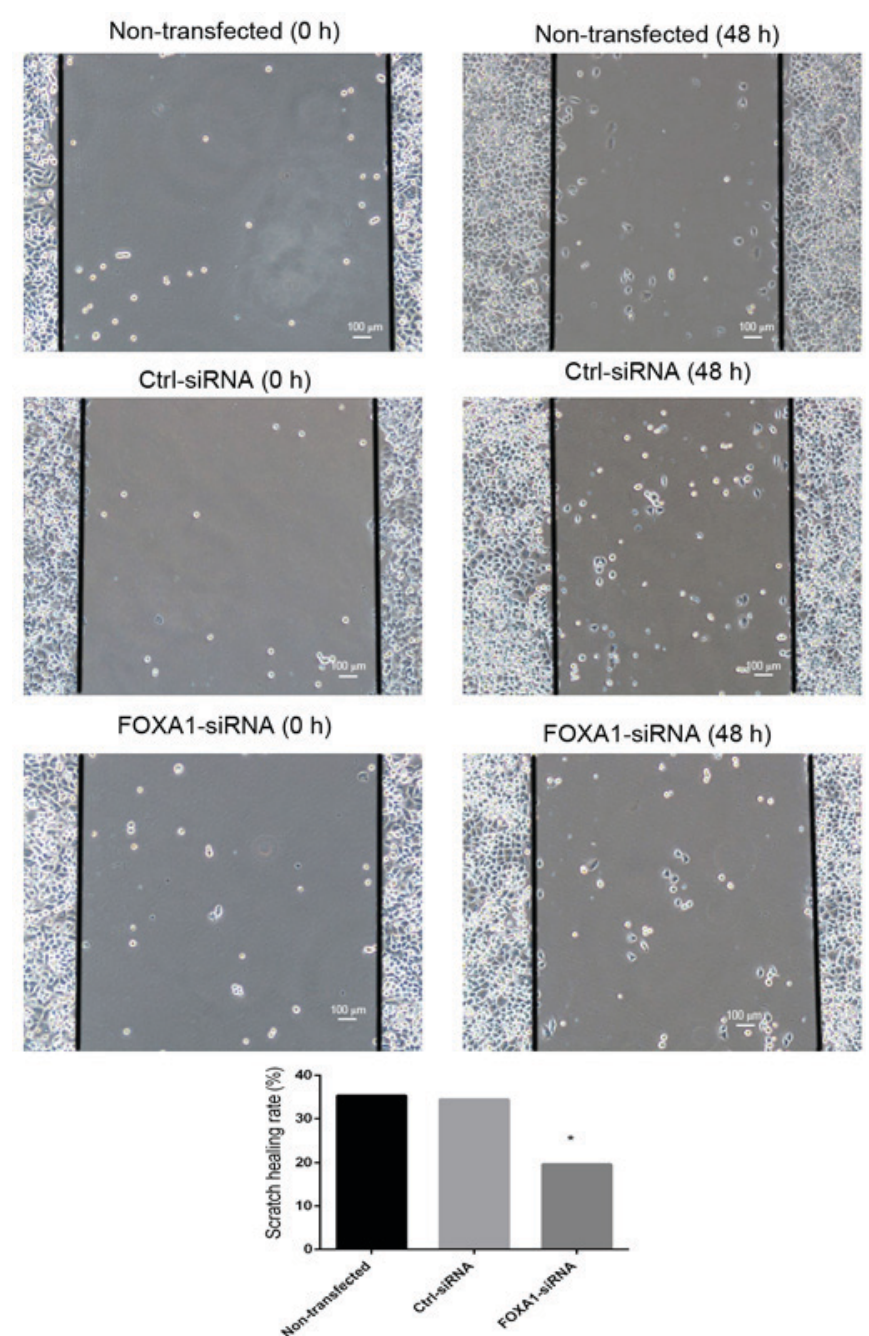

Figure 6. Cell migration of A549 cells with high invasive potential in the scratch wound assay following transfection with FOXA1 siRNA (magnification, $\mathrm{x} 100)$. The scratch healing rate in the FOXA1-siRNA cells was lower than that in the Ctrl-siRNA and non-transfected cells ( $\mathrm{P}<0.05)$. FOXA1, forkhead box protein A1; Ctrl, control; siRNA, small interfering RNA.

intracranial metastasis during the course of treatment $(5,6)$, representing one of the major causes of treatment failure of late-stage NSCLC-targeted molecules. Although there has been progress in elucidating the molecular mechanisms underlying lung cancer metastasis, successful translation into clinical application has been limited. Therefore, it is important to investigate the molecular mechanisms underlying lung 
Table IV. Effect of FOXA1-siRNA on H-INV A549 cell cycle.

Cells in phase $(\%)$

\begin{tabular}{lcrr} 
& Non-transfected & Ctr-siRNA & FOXA1-siRNA \\
\hline G0/G1 & $49.31 \pm 3.20$ & $49.69 \pm 3.51$ & $58.99 \pm 3.20^{\mathrm{a}}$ \\
S & $42.35 \pm 0.53$ & $42.49 \pm 1.16$ & $36.90 \pm 2.05^{\mathrm{a}}$ \\
G2/M & $7.63 \pm 3.48$ & $7.58 \pm 0.25$ & $4.10 \pm 1.12^{\mathrm{a}}$ \\
\hline
\end{tabular}

Data are presented as the mean \pm standard deviation. ${ }^{\mathrm{a}}<0.05$ vs. Ctrl-siRNA and non-transfected groups. H-INV, high invasive potential; FOXA1, forkhead box protein A1; Ctrl, control; siRNA, small interfering RNA.
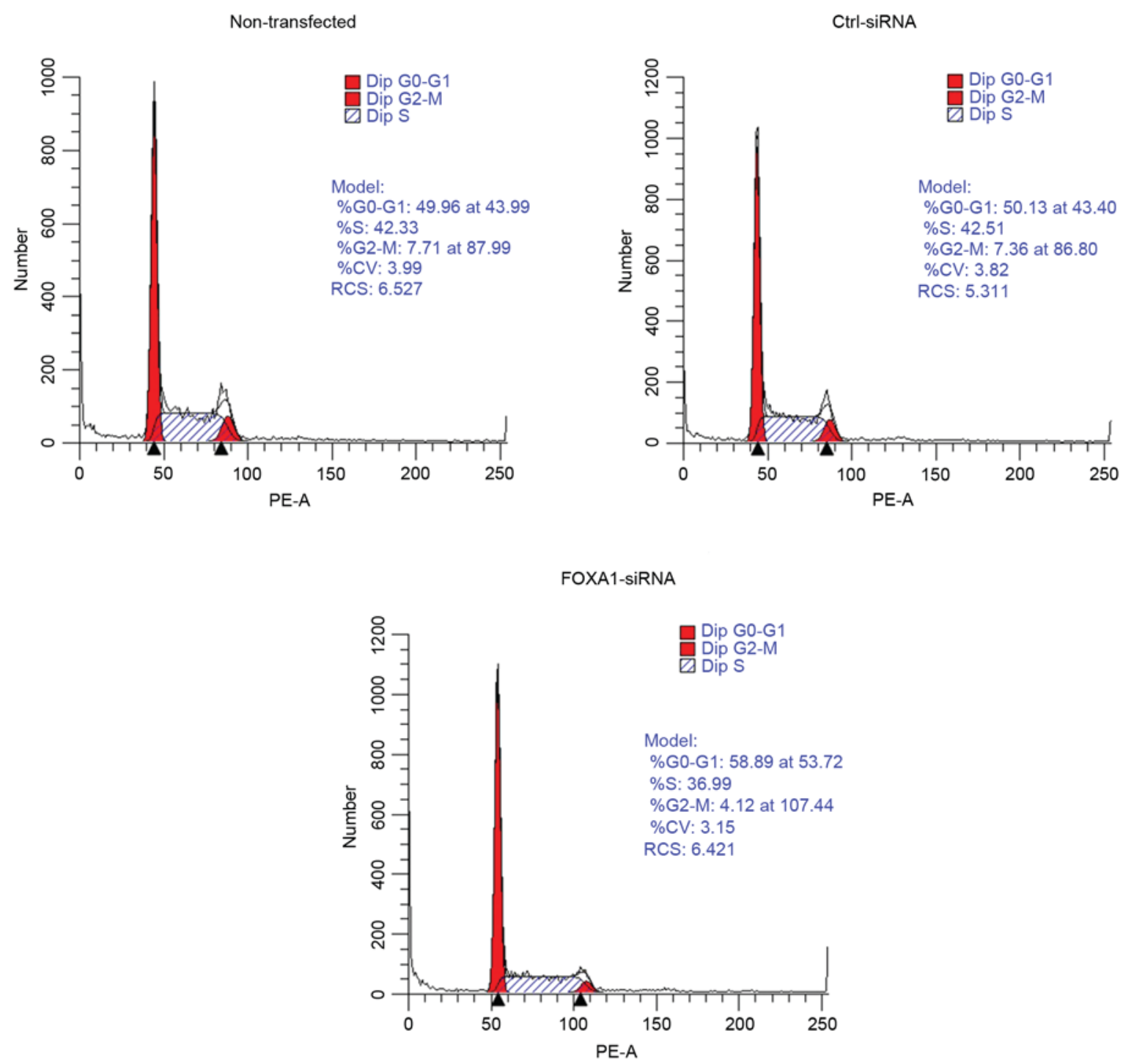

Figure 7. Cell cycle of A549 cells with high invasive potential following transfection with FOXA1 siRNA. FOXA1, forkhead box protein A1; Ctrl, control; siRNA, small interfering RNA.

cancer metastasis in a stable and effective model to identify biomarkers potentially associated with lung cancer metastasis, and to ensure effective prevention and treatment of lung cancer metastasis.

Based on its significantly high expression in the H-INV subpopulation of A549 cells, FOXA1 was selected in the present study for investigation in subsequent experiments. FOXA1 contains a forkhead (or winged helix) DNA-binding domain of $\sim 100$ amino acids and is a member of the pioneer FOXA transcription factor family. The transcription factor FOXA1 binds to the chromosome and induces nucleosome remodelling to facilitate the binding of other transcription 
factors on the chromosome to initiate tissue-specific transcriptional programmes (7-11). Previous studies have identified FOXA1 as either a pro- or anti-tumourigenic factor in specific human malignancies. For example, $40 \%$ of breast carcinoma cases and up to $80 \%$ of estrogen receptor-positive breast carcinoma are positive for FOXA1, and the expression of FOXA1 is associated with improved prognosis (12). In endometrial cancer, FOXA1 also functions as a tumour suppressor in cancer progression (13). By contrast, the expression levels of FOXA1 in prostate cancer are positively correlated with tumour size, extraprostatic extension and lymph node metastasis, and negatively correlated with patient survival rates (14). In pancreatic cancer, the loss of FOXA1 is necessary and sufficient for epithelial to mesenchymal transition during cancer progression (15). The overexpression and amplification of FOXA1 have also been observed in oesophageal, colorectal and thyroid cancer, and FOXA1 is considered a potential oncogene (16-18). In addition, Deutsch et al reported that the expression of FOXA1 in squamous cell carcinoma of the lung was associated with distant metastasis and an unfavourable survival rate; it was also found that the expression of FOXA1 in brain metastasis samples from patients with squamous cell cancer was marginally higher, compared with that in non-matched primary tumours (56 vs. 43\%) (19). In the present study, the combined analysis of all tumour samples confirmed that FOXA1 mRNA was expressed in the primary lesions and metastatic lymph nodes, with higher expression levels in the metastatic lymph nodes, compared with the primary lesions. This suggested that FOXA1 is important in the tumourigenesis and progression of NSCLC.

The present study further demonstrated the role of FOXA1 in the invasion, migration and proliferation of NSCLC cells in vitro. Using the A549 NSCLC cell line, the importance of FOXA1 in NSCLC metastasis was confirmed. In addition, the proliferation assay and flow cytometric analysis revealed the reduced proliferation of FOXA1-siRNA cells due to cell cycle arrest at the G0/G1 phase, suggesting that FOXA1 affected the transformation of tumour cells. FOXA1 has also been shown to promote epithelial to mesenchymal transition in A549 NSCLC cells (20), and the overexpression of FOXA1 inhibits the pro-apoptotic, anti-invasive and anti-migratory capacities of miR-194 in H1299 and A549 NSCLC cells (21). FOXA1 also promotes the migration and invasion of H1299, PC9 and A549 lung adenocarcinoma cancer cells (22).

In conclusion, the results of the present study suggested that FOXA1 is a potential oncogene in NSCLC; therefore, specific interference of the expression of FOXA1 may represent a novel approach for the treatment of NSCLC.

\section{Acknowledgements}

The present study was supported by the Major Science and Technology Innovation Project of Hangzhou (grant no. 20112312A01 to Professor Shenglin Ma), the Zhejiang Medical Science Foundation of China (grant no. 2014KYA178 to Mrs. Shirong Zhang), the Hangzhou Key Disease and Discipline Foundation of China (grant no. 20140733Q15 to Mrs. Shirong Zhang) and the Zhejiang Provincial Natural
Science Foundation of China (grant no. LY15H160010 to Mrs. Shirong Zhang).

\section{References}

1. Jemal A, Bray F, Center MM, Ferlay J, Ward E and Forman D: Global cancer statistics. CA Cancer J Clin 61: 69-90, 2011.

2. Zhang S, Wu K, Feng J, Wu Z, Deng Q, Guo C, Xia B, Zhang J, Huang H, Zhu L, et al: Epigenetic therapy potential of suberoylanilide hydroxamic acid on invasive human non-small cell lung cancer cells. Oncotarget 7: 68768-68780, 2016.

3. Livak KJ and Schmittgen TD: Analysis of relative gene expression data using real-time quantitative PCR and the 2(-Delta Delta C(T)) methods. Methods 25: 402-408, 2001.

4. Coleman RE: Clinical features of metastatic bone disease and risk of skeletal morbidity. Clin Cancer Res 12: 6243-6249, 2006.

5. Omuro AM, Kris MG, Miller VA, Franceschi E, Shah N, Milton DT and Abrey LE: High incidence of disease recurrence in the brain and leptomeninges in patients with non-small cell lung carcinoma after response to gefitinib. Cancer 103: 2344-2348, 2005.

6. Lee YJ, Choi HJ, Kim SK, Chang J, Moon JW, Park IK, Kim JH and Cho BC: Frequent central nervous system failure after clinical benefit with epidermal growth factor receptor tyrosine kinase inhibitors in Korean patients with non small-cell lung cancer. Cancer 116: 1336-1343, 2010.

7. Cirillo LA and Zaret KS: An early developmental transcription factor complex that is more stable on nucleosome core particles than on free DNA. Mol Cell 4: 961-969, 1999.

8. Zaret K: Developmental competence of the gut endoderm: Genetic potentiation by GATA and HNF3/fork head proteins. Dev Biol 209: 1-10, 1999.

9. Cirillo LA, Lin FR, Cuesta I, Friedman D, Jarnik M and Zaret KS: Opening of compacted chromatin by early developmental transcription factors HNF3 (FoxA) and GATA-4. Mol Cell 9: 279-289, 2002.

10. Carroll JS, Liu XS, Brodsky AS, Li W, Meyer CA, Szary AJ, Eeckhoute J, Shao W, Hestermann EV, Geistlinger TR, et al: Chromosome-wide mapping of estrogen receptor binding reveals long-range regulation requiring the forkhead protein FoxA1. Cell 122: 33-43, 2005.

11. Laganiere J, Deblois G, Lefebvre C, Bataille AR, Robert F and Giguere V: From the cover: Location analysis of estrogen receptor alpha target promoters reveals that FOXA1 defines a domain of the estrogen response. Proc Natl Acad Sci USA 102: 11651-11656, 2005.

12. Albergaria A, Paredes J, Sousa B, Milanezi F, Carneiro V, Bastos J, Costa S, Vieira D, Lopes N, Lam EW, et al: Expression of FOXA1 and GATA-3 in breast cancer: The prognostic significance in hormone receptor-negative tumors. Breast Cancer Res 11: R40, 2009.

13. Abe Y, Ijichi N, Ikeda K, Kayano H, Horie-Inoue K, Takeda S and Inoue S: Forkhead box transcription factor, forkhead box A1, shows negative association with lymph nodes status in endometrial cancer, and represses cell proliferation and migration of endometrial cancer cells. Cancer Sci 103: 806-812, 2012.

14. Sahu B, Laakso M, Ovaska K, Mirtti T, Lundin J, Rannikko A, Sankila A, Turunen JP, Lundin M, Konsti J, et al: Dual role of FOXA1 in androgen receptor binding to chromatin, androgen signaling and prostate cancer. EMBO J 30: 3962-3976, 2011.

15. Song Y, Washington MK and Crawford HC: Loss of FOXA1/2 is essential for the epithelial-to-mesenchymal transition in pancreatic cancer. Cancer Res 70: 2115-2125, 2010.

16. Lin L, Miller CT, Contreras JI, Prescott MS, Dagenais SL, Wu R, Yee J, Orringer MB, Misek DE, Hanash SM, et al: The hepatocyte nuclear factor 3 alpha gene, HNF3alpha (FOXA1), on chromosome band 14q13 is amplified and overexpressed in esophageal and lung adenocarcinomas. Cancer Res 62: 5273-5279, 2002.

17. Ma W, Jiang J, Li M, Wang H, Zhang H, He X, Huang L and Zhou Q: The clinical significance of forkhead box protein A1 and its role in colorectal cancer. Mol Med Rep 14: 2625-2631, 2016.

18. Nucera C, Eeckhoute J, Finn S, Carroll JS, Ligon AH, Priolo C, Fadda G, Toner M, Sheils O, Attard M, et al: FOXA1 is a potential oncogene in anaplastic thyroid carcinoma. Clin Cancer Res 15: 3680-3689, 2009. 
19. Deutsch L, Wrage M, Koops S, Glatzel M, Uzunoglu FG, Kutup A, Hinsch A, Sauter G, Izbicki JR, Pantel K and Wikman H: Opposite roles of FOXA1 and NKX2-1 in lung cancer progression. Gene Chromosome Canc 51: 618-629, 2012.

20. Wang H, Meyer CA, Fei T, Wang G, Zhang F and Liu XS: A systematic approach identifies FOXA1 as a key factor in the loss of epithelial traits during the epithelial-to-mesenchymal transition in lung cancer. BMC Genomics 14: 680, 2013.
21. Zhu X, Li D, Yu F, Jia C, Xie J, Ma Y, Fan S, Cai H, Luo Q, Lv Z and Fan L: miR-194 inhibits the proliferation, invasion, migration, and enhances the chemosensitivity of non-small cell lung cancer cells by targeting forkhead box A1 protein. Oncotarget 7: 13139-13152, 2016

22. Wang R, Shi Y, Chen L, Jiang Y, Mao C, Yan B, Liu S, Shan B, Tao Y and Wang X: The ratio of FOXA1 to FOXA2 in lung adenocarcinoma is regulated by LncRNA HOTAIR and chromatin remodeling factor LSH. Sci Rep 5: 17826, 2015. 